\title{
MANUFACTURE AND EVALUATION OF A COMBINATION MACHINE FOR SEED BED \\ PREPARATION, WATER HARVESTING AND PLANTING UNDER RAINFED AGRICULTURAL CONDITIONS
}

Morad, M. M.*

and

M. M. Ali**

\section{ABSTRACT}

Experiments were carried out to manufacture and evaluate the performance of a combination machine suitable for seed bed preparation, water harvesting and planting under rain fed agricultural conditions. The manufactured machine was compared with the traditional method under the same conditions. The machine performance was studied as a function of change in machine forward speed and plowing depth. Performance evaluation of the manufactured machine was carried out in terms of bulk density, and infiltration rate as a soil measurements; crop yield as a crop measurements; runoff and water use efficiency as a water measurements; field capacity and efficiency, required power, energy requirements and operational cost as a machine measurements. The experimental results reveal that the manufactured machine decreased runoff volume, energy and cost while increased crop yield and water use efficiency under the following conditions:

- The use of the manufactured machine instead of the traditional method.

- Machine forward speed of between 3.5 to $4.5 \mathrm{~km} / \mathrm{h}$.

- Plowing depth of between 10 to $15 \mathrm{~cm}$.

\section{INTRODUCTION}

$\mathrm{W}$ ater is essential to all life - human, animal and vegetation. It is therefore important that adequate supplies of water be developed to sustain such life. Water harvesting (WH) is defined as the process of concentrating rainfall as runoff from a larger area for use in a smaller target area where the collected water is either directly applied to the cropping area or stored in the soil profile for immediate use by the crop.

\footnotetext{
"Prof. of Agric. Eng., Fac. of Agric., Zagazig Univ., Egypt.

Assoc. Prof. of Agric. Eng., Fac. of Agric., Zagazig Univ., Egypt.
} 
Micro-catchments water harvesting for increasing crop production on dry land has been the subject of considerable research for the last decades. Hackwell et al. (1991) and Rochester et al. (1994) defined reservoir tillage as a system in which numerous small surface depressions are formed to collect and hold water during rainfall or irrigation to prevent surface run-off. However, currently, reservoir tillage is used predominantly for soil erosion control in environments with higher annual but lower intensity rainfall than semi-arid environments. Typically, depressions are formed in compression by the use of a number of weighted, toothed discs that are towed behind a tractor in recently tilled soils to form isolated, approximately $0.5-\mathrm{L}$ capacity, trapezoidal-shaped impressions in the surface. This method has potential to benefit semi-arid environments. Hansen and Trimmer (1997) reported that reservoirs or basins are created with specialized commercially available tillage machines, which catch and hold water in place until it can infiltrate into the soil. Two basic methods are commonly used to construct reservoirs. One method is pitting-punching holes or depressions 15 to $25 \mathrm{~cm}$ in diameter, 15 to $20 \mathrm{~cm}$ deep, and spaced about $60 \mathrm{~cm}$ on center into the soil. The other method builds up small earthen dams or dikes with a tillage tool that scrapes and carries loose soil down the furrow. The tool trips at preset intervals, creating small dams in the furrows to retain rainwater. Small basins created by these dikes hold the precipitation until it can infiltrate the soil. Ventura et al. (2003) reported a new reservoir tillage system for crop production in semi-arid areas. The system included horizontal soil subsoiler, a modified raw planter and a roller formed with plastic wheels to improve soil tilt and create mini-reservoirs on the soil surface for rain water harvesting. They found that the new reservoir tillage delayed runoff by about 20 minutes over control treatment when a rainfall of $40 \mathrm{~mm} / \mathrm{hr}$ was simulated. Patrick et al. (2007) reported that reservoir tillage is an effective method of harvesting water and thus reducing erosion in semiarid areas on light textured soils, such as sandy loam soil. Use of marginal areas in semi-arid environments for agricultural production 
commonly includes light textured soils on slopes that are prone to erosion. Also they showed that depressions were able to harvest up to $95 \%$ of surface run-off for slopes of up to 10 for the given geometry of the depressions used, this level of water harvesting can be achieved if depressions are orientated with the longitudinal axis across the slope and arranged in a staggered configuration. These results suggest that, for optimized water harvesting, the quell should be operated across slope as is common with other tillage practices on moderate slopes. Therefore, there is a need to design integrated technologies to increase agricultural water use efficiency through rainwater harvesting while conserving the soil in rainfed areas.

\section{So, the objectives of this study are to:}

- Manufacture of a combination machine suitable for seed bed preparation, water harvesting and planting under rainfed agricultural conditions.

- Optimize some different operating parameters affecting the performance of the manufactured machine.

- Compare the manufactured machine with the traditional method from the economic point of view.

\section{MATERIALS AND METHODS}

Field experiments were carried out through two agricultural seasons of 2009/2010 and 2010/2011 at Wadi Madwar, El- Qasr area south west of Marsa Matruh city, in the North-Western Coast. The mechanical analysis of the experimental soil is classified as a sandy loam soil. Soil mechanical analysis and some soil characteristics are shown in Table (1).

Table (1): Some soil characteristics of the experimental soil

\begin{tabular}{|c|c|c|c|c|c|c|c|c|c|}
\hline \multirow{2}{*}{$\begin{array}{l}\text { Soil } \\
\text { depth, } \\
\mathrm{cm}\end{array}$} & \multirow[b]{2}{*}{$\mathrm{PH}$} & \multirow{2}{*}{$\begin{array}{l}\text { E.C, } \\
\text { ds.m }{ }^{-1}\end{array}$} & \multirow{2}{*}{$\begin{array}{c}\text { Bulk } \\
\text { density } \\
, \mathrm{g} / \mathrm{cm}^{3}\end{array}$} & \multirow{2}{*}{$\begin{array}{c}\mathrm{Ca} \\
\mathrm{Co}_{3}, \\
\%\end{array}$} & \multicolumn{4}{|c|}{ Particle size distribution, $\%$} & \multirow{2}{*}{$\begin{array}{l}\text { Soil } \\
\text { texture }\end{array}$} \\
\hline & & & & & $\begin{array}{c}\text { Coarse } \\
\text { sand }\end{array}$ & $\begin{array}{l}\text { Fine } \\
\text { sand }\end{array}$ & Silt & Clay & \\
\hline $0-20$ & 7.8 & 11.9 & 1.6 & 11.9 & 32.5 & 35.8 & 13.6 & 18.1 & Sandy loam \\
\hline $20-40$ & 7.8 & 15.4 & 1.62 & 15.9 & 24.7 & 43.7 & 12.4 & 19.2 & Sandy loam \\
\hline
\end{tabular}




\section{MATERIALS}

1.1. The used crop: Barley (Hordeum vulgar L.) Giza 123 variety was used in this study. The used crop is cultivated in 1 December and harvested in 25 May.

1.2. The irrigation water: Rainfall is the source of irrigation water in the experimental area. In Egypt, rain is considered the main source for agricultural activity particularly in north-west coastal zone. Rain water harvesting in Egypt may secure millions of $\mathrm{m} 3$ of water/year. The main climatic data in the experimental area are shown in Tale (2). The accumulation of rainfall water quantities from December to April are considered the amount of applied water to barley crop.

Table (2): Main climatic data in Matruh, North west, Egypt.

\begin{tabular}{|c|c|c|c|c|c|c|c|c|c|c|c|c|}
\hline \multirow{2}{*}{ Parameter } & \multicolumn{12}{|c|}{ Year months } \\
\hline & Jan & Feb & Mar & Apr & May. & June & July & Aug & Sep & Oct & Nov & Des \\
\hline Rainfall, $\mathrm{mm} / \mathrm{d}$ & 1.29 & 0.71 & 0.40 & 3.80 & 0.13 & 0.04 & 0.00 & 0.03 & 1.50 & 0.05 & 0.79 & 1.20 \\
\hline Max. temp., ${ }^{0} \mathrm{C}$ & 18.0 & 18.8 & 20.2 & 22.8 & 25.9 & 27.1 & 29.1 & 29.8 & 28.6 & 27.0 & 23.3 & 19.8 \\
\hline Min. temp., ${ }^{0} \mathrm{C}$ & 8.0 & 8.1 & 9.6 & $\mid 11.7$ & 14.5 & 18.1 & 20.1 & 18.1 & 19.6 & 16.7 & 13.2 & 10.0 \\
\hline Air humidity, \% & 61.9 & 58.3 & 57.1 & 57.6 & 57.4 & 59.7 & 64.5 & 63.4 & 62.9 & 51.4 & 64.6 & 60.4 \\
\hline $\mathrm{E} \mathrm{T}_{0}, \mathrm{~mm} / \mathrm{d}$ & 3.0 & 2.87 & 3.87 & 4.87 & 5.33 & 5.27 & 5.27 & 5.83 & 5.0 & 4.33 & 3.33 & 3.0 \\
\hline
\end{tabular}

1.3. The power source: four strokes - Diesel engine tractor of $87 \mathrm{hp}$ $(65.3 \mathrm{~kW})$ was used as a power source

\subsection{The local manufactured combination machine: A local} manufactured combination (multi-purposes) machine, suitable for seed bed preparation, water harvesting and planting under rainfed agricultural conditions was manufactured from low cost, local material to overcome the problems of high power and high cost requirements under the use of the imported machines or under the use of the traditional methods. The manufactured machine is shown in Figs. (1 and 2). The combination machine was manufactured and developed in a local engineering workshop, Sharkia Governorate. It consists of the following main parts: 


\begin{tabular}{|c|c|c|}
\hline No. & Part name & No. of \\
\hline 1 & Seed hopper & 1 \\
\hline 2 & Main frame & 1 \\
\hline 3 & Spikes & 42 \\
\hline 4 & Roller & 1 \\
\hline 5 & $\begin{array}{c}\text { Transmission } \\
\text { system }\end{array}$ & 1 \\
\hline 6 & Ground wheel & 2 \\
\hline 7 & Chisel blade & 4 \\
\hline 8 & Seed tubes & 7 \\
\hline 9 & $\begin{array}{c}\text { Three points } \\
\text { hitch }\end{array}$ & 1 \\
\hline
\end{tabular}

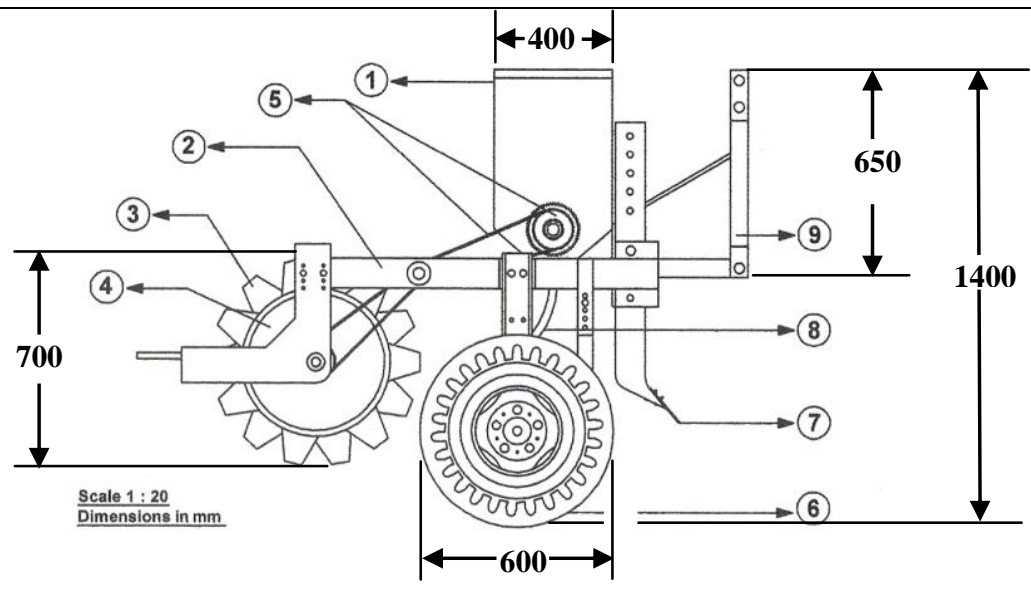

Fig.1: Side view of the manufactured combination machine.

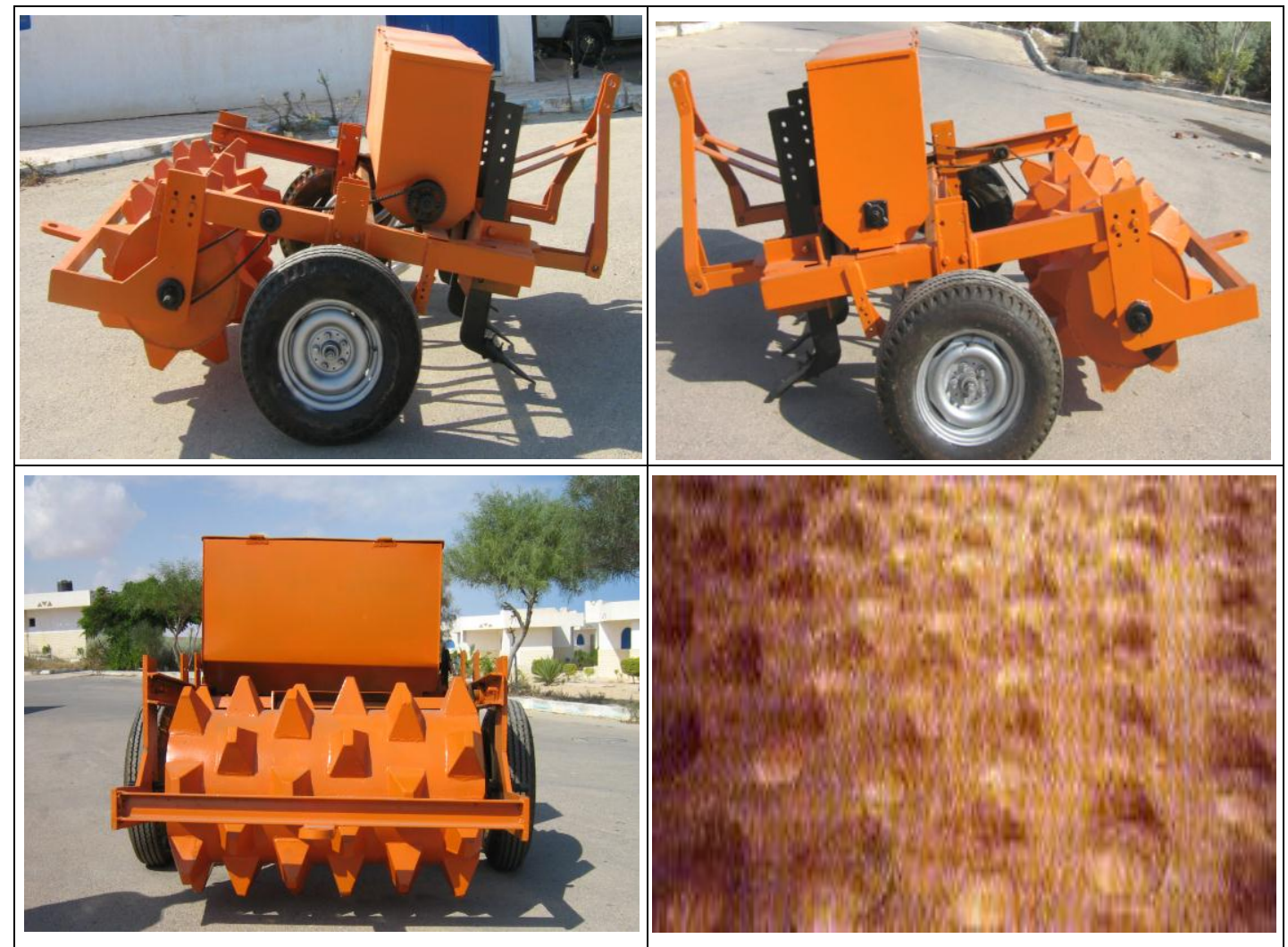

Fig. 2: Photos of the manufactured combination machine and the experimental area with the mini reservoirs made by the machine 
-Frame and wheels: The frame is made of rectangular iron sheet steel. The frame is of $220 \mathrm{~cm}$ length, $210 \mathrm{~cm}$ width and $140 \mathrm{~cm}$ height. It includes elements to fix the chisel plow, the seed drill, the spiked roller and the transmission system. It was carried by two ground wheels of 60 cm diameter.

- Four shares chisel plow: Four shares chisel plow were attached to the machine frame. The distance between each two shares is $50 \mathrm{~cm}$. The shares are used to plow the soil to conserve moisture in the effective root zone.

- Seed drill: Seed drill which is attached to the machine frame contains seed hopper, feeding unit, seed tubes and drill coulters. The seed drill is used to carry out mechanical planting in uniform rows $(7$ rows, $25 \mathrm{~cm}$ between each) for planting seed at a controlled depth and in specified amounts.

- Heavy spiked roller: Heavy spiked roller of $150 \mathrm{~cm}$ length and $50 \mathrm{~cm}$ diameter is attached to the machine frame through its shaft. Spikes with a length of $10 \mathrm{~cm}$ are distributed on the roller in rows. The distance between spikes in the same row is $35.5 \mathrm{~cm}$. The spiked roller creates mini-reservoirs (holes) on the soil surface for rainwater harvesting and reduces soil erosion and runoff.

- The transmission system: Motion is transmitted from the machine ground wheel to the seed drill feeding device shaft by means of pulleys and belts with different reduction speed ratios.

\section{Equipment used under the traditional method:}

- Chisel plow: Mounted chisel plow three point hitch, made in Behera Company, Egypt, 7 blades, $175 \mathrm{~cm}$ working width and $225 \mathrm{~kg}$. mass.

- Traditional water harvesting machine: Trailed machine, local made, $150 \mathrm{~cm}$ working width (Fig. 3).

- Seed drill: Mounted seed drill three point hitch, model Colorado, made in Italy, 8 tubes, $25 \mathrm{~cm}$ spacing between tubes, $350 \mathrm{~kg}$. mass. 


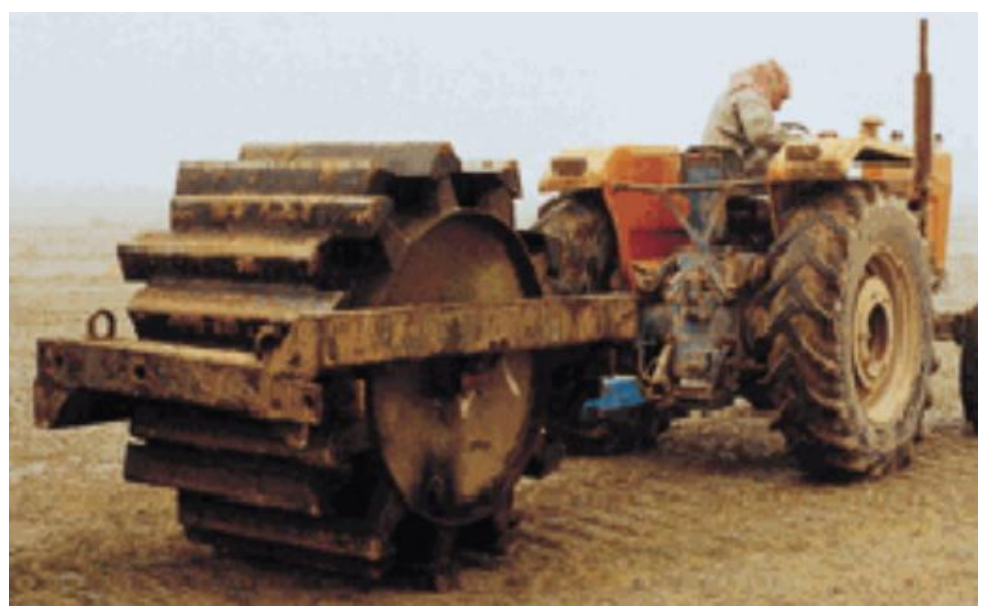

Fig. 3: Traditional water harvesting machine

\section{2- METHODS}

Experiments were carried out in an area of 3.0 feddans to optimize values of the main operating parameters affecting the performance of the manufactured machine during planting barley.

Two main experiments were carried:

- The first experiment was conducted using the traditional method (seed bed preparation by chisel plow, water harvesting by the traditional water harvesting machine and planting by seed-drill.

- The second experiment was carried out using the manufactured combination machine for seed bed preparation, water harvesting and planting in one pass.

2.1. Experimental conditions: The performance of the manufactured machine was experimentally measured under the following parameters:

- Four different forward speeds $(2.5,3.5,4.5$ and $5.5 \mathrm{~km} / \mathrm{h})$.

- Four different plowing depths (10, 15 and $20 \mathrm{~cm})$.

- The manufactured machine comparing with the traditional method.

2.2. Measurements and determinations: Performance Evaluation of the the manufactured machine was based on the following indicators:

\subsubsection{Soil measurements}

- Soil bulk density: Bulk density was calculated using the following formula (Black et al., 1965):

$$
\rho_{b}=m / v
$$


Where: $\rho_{\mathrm{b}}$ - Soil bulk density, $\mathrm{g} / \mathrm{cm}^{3}$,

$\mathrm{m}$ - Soil sample mass, $\mathrm{g}$,

$\mathrm{v}$ - Soil sample volume, $\mathrm{cm}^{3}$.

- Infiltration rate: Infiltration rate was determined using double ring at three different sites along furrow for each treatment according to (Cuenca 1989).

\subsubsection{Plant measurements}

- Crop yield: Randomized samples of the harvested crop were taken from all treatments to measure the following:

- Grain yield, kg/fed,

- Straw yield, kg/fed,

- Total yield (Grain Yield + Straw yield), kg/fed.

\subsubsection{Water measurements}

- Runoff: Runoff volume was measured using Girlish trough (0.5 m long and $0.2 \mathrm{~m}$ wide), FAO 1993, at the end of slope.

-Water use efficiency (WUE): Water use efficiency was determined as follows:

WUE $\left(\mathrm{kg} / \mathrm{m}^{3}\right)=$ Average yield $(\mathrm{kg} / \mathrm{fed}) /$ Amount of applied water $\left(\mathrm{m}^{3} / \mathrm{fed}\right)$

\subsubsection{Machine performance measurements}

- Actual field capacity (A.F.C): The actual field capacity was calculated by using the following equation:

$$
\text { A.F.C }=\frac{1}{T} \mathrm{fed} / \mathrm{h}
$$

Where:

T- Actual time consumed for planting one feddan, h/fed.

- Field efficiency $\left({ }^{\eta_{f}}\right)$ : Field efficiency was calculated using the following equation:

Where:

$$
\eta_{\mathrm{f}}=\frac{\text { A.F.C }}{\text { T.F.C }} \times 100
$$

T.F.C- Theoretical field capacity is calculated by multiplying machine forward speed by the effective working width of the machine. 
- Fuel consumption: Fuel consumption was recorded by accurately measuring the decrease in fuel level in the fuel tank immediately after executing each operation.

- Required power: The required power was calculated by using the following formula (Hunt, 1983):

$$
R . P=(F . c / 3600) \times \rho \times C . V \times \eta_{m} \times \eta_{t h} \times 427 \times \frac{1}{75} \times \frac{1}{1.36} k W
$$

Where: $\mathrm{R} \mathrm{P}$ - The required power, $\mathrm{kW}$;

F. c - Fuel consumption, $\mathrm{kg} / \mathrm{s}$;

$\rho$ - Density of density, $\mathrm{kg} / \mathrm{m} 3$

C.V - Calorific value of fuel, $\mathrm{kcal} / \mathrm{kg}(\mathrm{C} . \mathrm{v}=10000 \mathrm{kcal} / \mathrm{kg})$

427 - Thermo mechanical equivalent, $\mathrm{kg} \cdot \mathrm{m} / \mathrm{k} \mathrm{cal}$;

$\eta_{t h}$ - Engine thermal efficiency, $\%$ ( $\eta_{t h}=30 \%$ for diesel engine).

- Energy requirements: Energy requirements can be calculated as follows:

Energy requirements $(\mathrm{kW} \cdot \mathrm{h} / \mathrm{Fed})=\frac{\text { Required power }(\mathrm{kW})}{\text { Actual field capacity }(\mathrm{Fed} / \mathrm{h})}$

- Operational cost: The machine cost (Hourly cost) was determined by using the following equation (Awady et al., 1978):

$$
C=\frac{P}{h}\left(\frac{1}{a}+\frac{i}{2}+t+r\right)+(0.9 \text { W.S.F })+\frac{m}{144}
$$

Where:

$C=$ Hourly cost, L.E/h.

$h=$ Yearly working hours, h/year. $\quad A=$ Life expectancy of the machine, $\mathrm{y}$.

$i=$ Interest rate/year.

$t=$ Taxes, over heads ratio.

$m=$ Monthly average wage, L.E

$W=$ Engine power, $\mathrm{hp}$.
$P=$ Price of machine, L.E.

$F=$ Fuel price, $\mathrm{L} . \mathrm{E} / \mathrm{l}$.

$R=$ Repairs and maintenance ratio.

$0.9=$ Factor accounting for lubrications .

$S=$ Specific fuel consumption, $l / h$.h.

$144=$ Reasonable estimation of monthly working hours.

The operational cost can be determined using the following formula:

$$
\text { Operational cost }=\frac{\text { Machine cost }(L . E / h)}{\text { Actual field capacity }(f e d / h)},(\text { L.E / fed })
$$




\section{RESULTS AND DISCUSSION}

The discussion will cover the obtained results under the following heads:

\section{Effect of some operating parameters on soil characteristics}

Results in Fig. (4) show that there are differences in soil bulk density and infiltration rate before and after using the combination machine. Bulk density generally decreased due to tillage while the vice versa is noticed with the infiltration rate. The maximum reduction of $43 \%$ in bulk density, while the maximum increase in infiltration rate of $29 \%$ were observed under forward speed of $2.5 \mathrm{~km} / \mathrm{h}$ and plowing depth of $20 \mathrm{~cm}$. This can be explained by the fact that bulk density decreased while infiltration rate increased due to tillage because of the breakdown of soil structure, increase pore spaces and therefore reduce bulk density.

The same results also show that increasing machine forward speed increased bulk density while decreased infiltration rate. Increasing machine forward speed from 2.5 to $5.5 \mathrm{~km} / \mathrm{h}$ increased bulk density from 0.95 to $1.35 \mathrm{~g} / \mathrm{cm} 3$, while decreased the infiltration rate from 3.2 to 1.3 $\mathrm{cm} / \mathrm{h}$ at a plowing depth of $15 \mathrm{~cm}$. This increase in bulk density and the decrease in infiltration rate by increasing forward speed are because of producing fewer breakdowns of soil aggregates.

The obtained data also show that increasing plowing depth decreased bulk density while increased the infiltration rate. Increasing plowing depth from $10 \mathrm{~cm}$ to $20 \mathrm{~cm}$ decreased bulk density from 1.12 to 0.9 $\mathrm{g} / \mathrm{cm} 3$, while increased the infiltration rate from 1.6 to $2.8 \mathrm{~cm} / \mathrm{h}$ at a forward speed of $3.5 \mathrm{~km} / \mathrm{h}$. This decrease in both bulk density and the increase in the infiltration rate by increasing plowing depth are attributed to the increase in soil crumbling and pore spaces.

\section{Effect of some operating parameters on crop characteristics}

Tillage as well as machine operating parameters has a great effect on the crop characteristics such as: grain yield and total crop yield. It was observed in Fig.(5) that the maximum grain yield of $920 \mathrm{~kg} / \mathrm{fed}$ was remarked under forward speed of $2.5 \mathrm{~km} / \mathrm{h}$ and plowing depth of $20 \mathrm{~cm}$. 


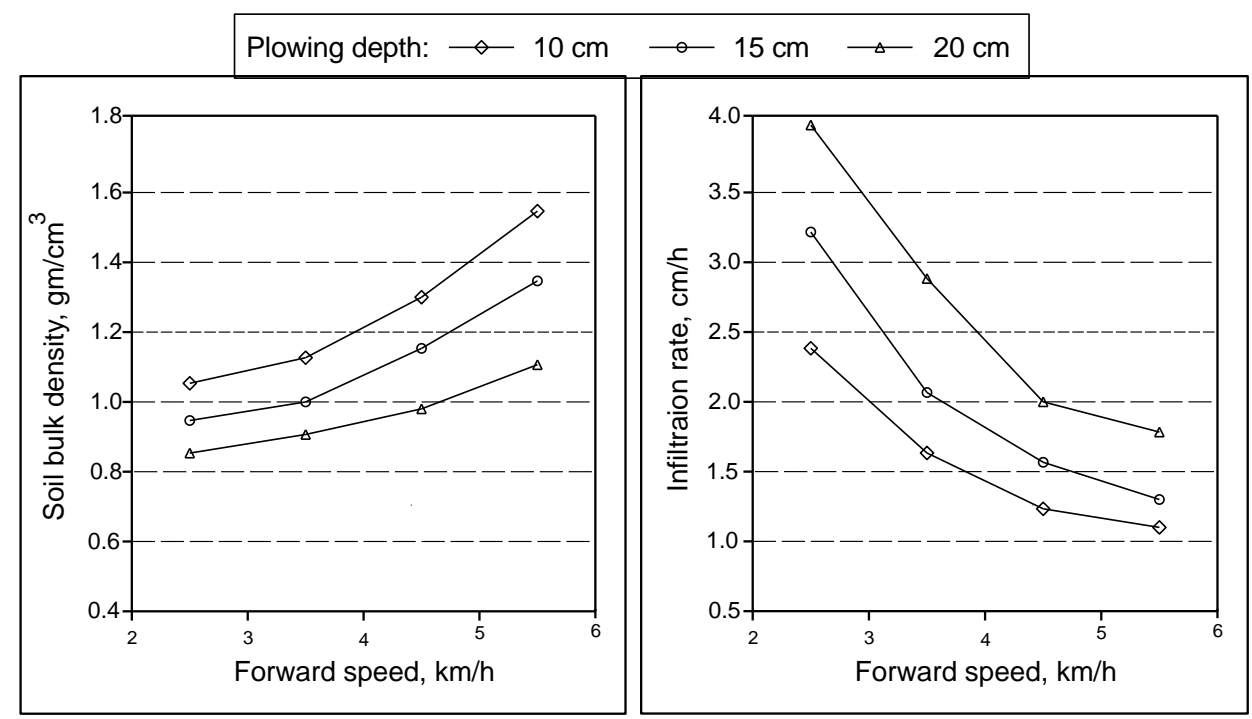

Fig. (4): Effect of machine forward speed on soil bulk density and infiltration rate under different plowing depths.

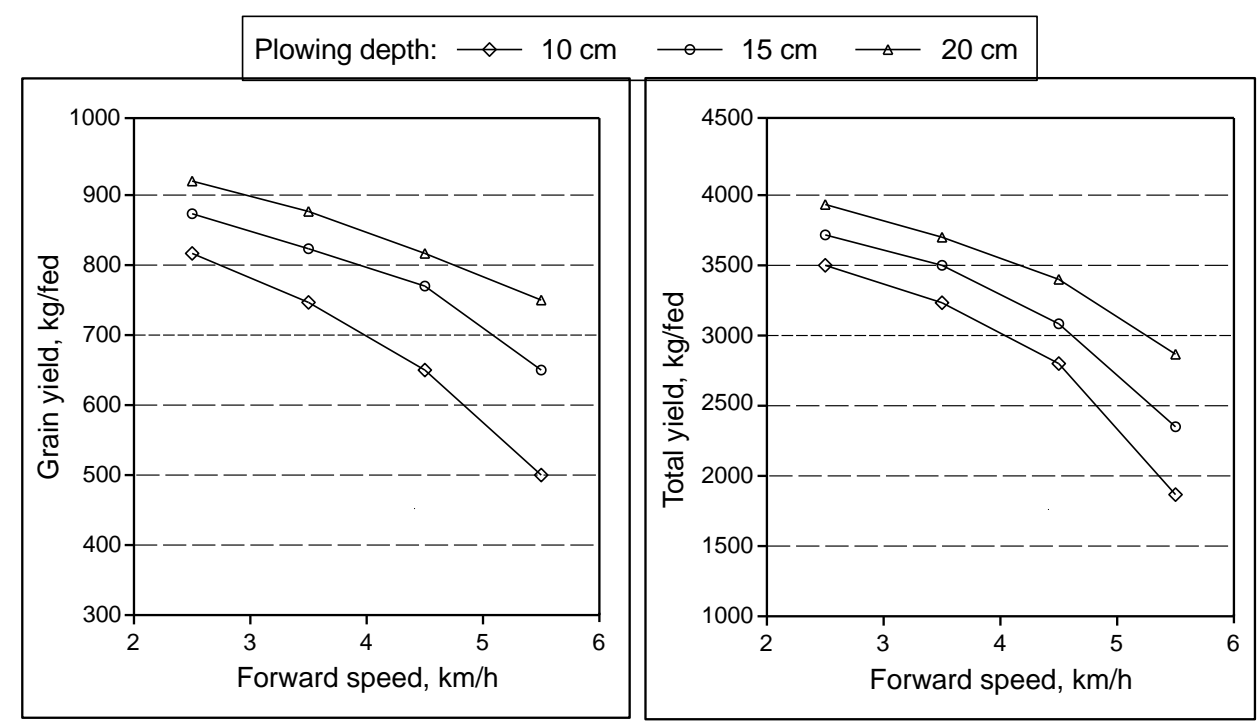

Fig. (5): Effect of machine forward speed on crop yield under different plowing depths. 
It decreased to $500 \mathrm{~kg} / \mathrm{fed}$ under forward speed of $5.5 \mathrm{~km} / \mathrm{h}$ and plowing depth of $10 \mathrm{~cm}$. Also data show that the maximum total crop yield of $3900 \mathrm{~kg} / \mathrm{fed}$ was noticed under forward speed of $2.5 \mathrm{~km} / \mathrm{h}$ and plowing depth of $20 \mathrm{~cm}$ while decreased to $1800 \mathrm{~kg} / \mathrm{fed}$ under forward speed of $5.5 \mathrm{~km} / \mathrm{h}$ and plowing depth of $10 \mathrm{~cm}$.

The decrease in both grain yield and total crop yield by increasing machine forward speed is due to the fact that the increase in forward speed affected structural stability and state of soil compaction of disturbed soil added to the increase of machine vibration resulting in an increase in seed scattering which affects negatively on crop yield. While the increase in grain yield and total crop yield by increasing plowing depth is due to the increase in soil pulverization. Added to that the stored water in the mini reservoirs, which are made by the manufactured machine, helps in increasing crop yield.

\section{Effect of some operating parameters on water characteristics}

Water characteristics are more sensitive to tillage and machine operating parameters. The manufactured combination machine decreases runoff and improves water use efficiency.

The values of runoff and water use efficiency are shown in Fig. (6) The minimum value of runoff and the maximum value of water use efficiency were $2.36 \mathrm{~mm}$ and $2.3 \mathrm{~kg} / \mathrm{m} 3$ respectively under forward speed of 2.5 $\mathrm{km} / \mathrm{h}$ and plowing depth of $20 \mathrm{~cm}$. While the maximum and minimum values were $4.8 \mathrm{~mm}$ and $1 \mathrm{~kg} / \mathrm{m} 3$ under forward speed of $5.5 \mathrm{~km} / \mathrm{h}$ and plowing depth of $10 \mathrm{~cm}$ under the same previous conditions.

The increase in runoff and the decrease in water use efficiency by increasing machine forward speed are attributed to the fact that the minireservoirs created by the developed machine at high speeds can not collect or store rainfall due to its bad form resulting from machine vibration. While the decrease in runoff and the increase in water use efficiency by increasing plowing depth is due to the fact that rainfall was collected in the mini-reservoirs made by the manufactured combination machine, allowing more time for infiltration which reduced runoff and increased water use efficiency. 


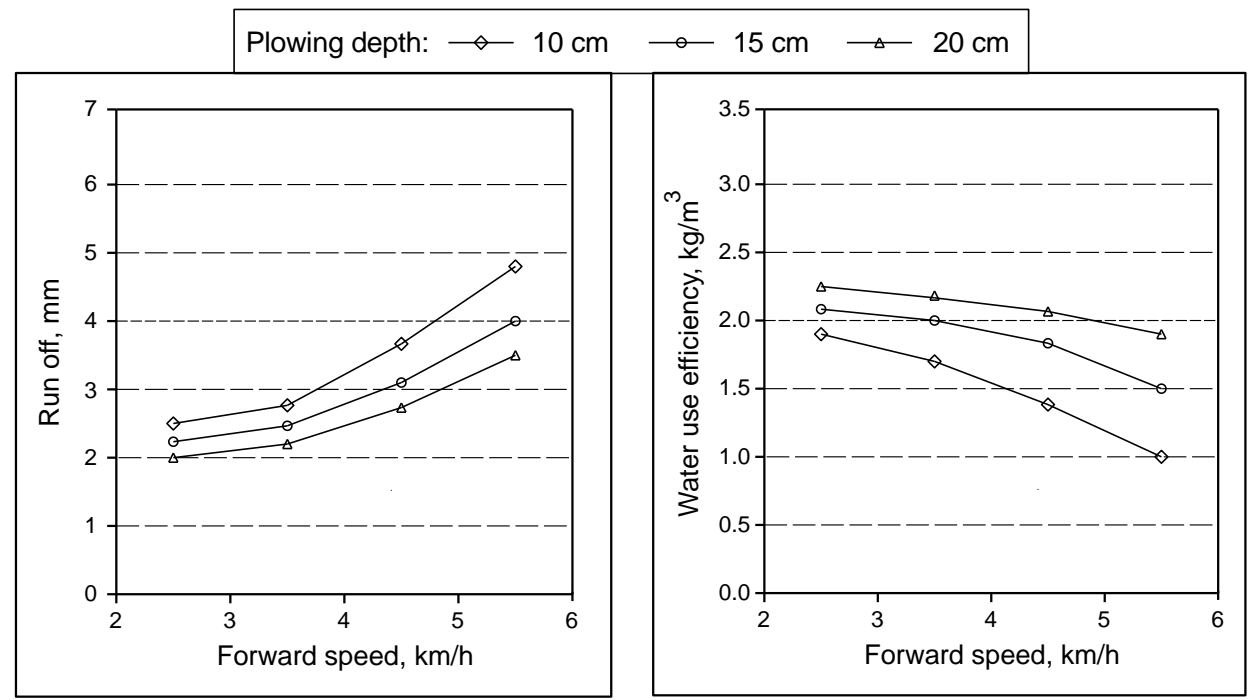

Fig. (6): Effect of machine forward speed on runoff and water use efficiency under different plowing depths.

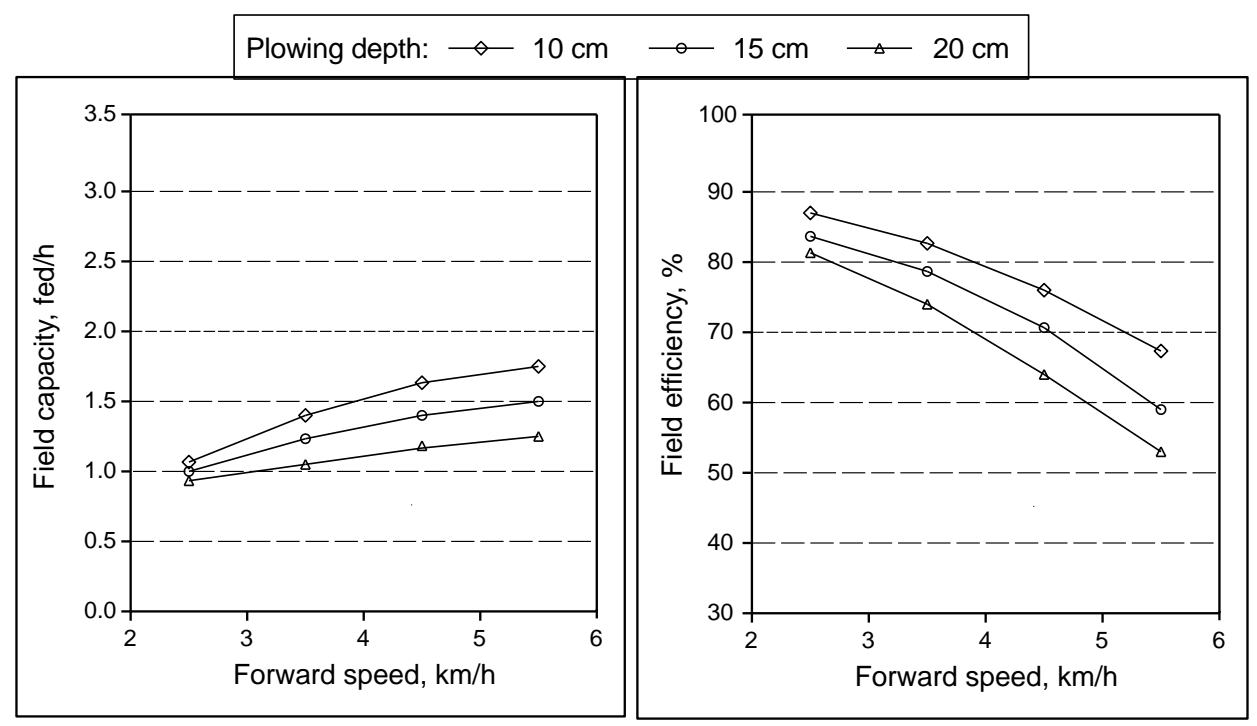

Fig. (7): Effect of machine forward speed on field capacity and field efficiency under different plowing depths. 


\section{Effect of some operating parameters on field capacity and field efficiency}

The effect of both forward speed and plowing depth on field capacity and field efficiency is shown in Fig. (7). Obtained results show a remarkable drop in the field efficiency with a consequent sharp rise in the field capacity as the forward speed increased, while the vice versa is noticed with the plowing depth. Increasing forward speed from 2.5 to $5.5 \mathrm{~km} / \mathrm{h}$, increased field capacity from 1.05 to 1.78 , from 1.0 to 1.5 and from 0.95 to $1.25 \mathrm{fed} / \mathrm{h}$, at plowing depths of 10,15 , and $20 \mathrm{~cm}$ respectively. The vice versa was noticed with the field efficiency, where the field efficiency decreased from 88 to 68 , from 84 to 57 , and from 80 to $50 \%$ under the same previous conditions. The major reason for the reduction in field efficiency as the forward speed increased is due to the less theoretical time consumed in comparison with the other items of time losses.

\section{Effect of some operating parameters on fuel, power and energy requirements}

Power and energy requirements are highly affected by both forward speed and plowing depth. Fig. (8) shows a remarkable drop in energy requirements as the forward speed increased up to $4.5 \mathrm{~km} / \mathrm{h}$. Any further increase in forward speed more than $4.5 \mathrm{~km} / \mathrm{h}$ up to $5.5 \mathrm{~km} / \mathrm{h}$ energy will increase, while required power increased all time by increasing forward speed. Increasing forward speed from 2.5 to $5.5 \mathrm{~km} / \mathrm{h}$, increased the required power from 18 to 26 from 19.5 to 29 and from 21 to $33 \mathrm{~kW}$ at plowing depths of 10,15 and $20 \mathrm{~cm}$ respectively. While increasing forward speed from 2.5 to $4.5 \mathrm{~km} / \mathrm{h}$, decreased energy requirements from 17 to 13 , from 20 to 17 and from 22 to $19.5 \mathrm{~kW}-\mathrm{h} /$ fed. Any further increase in forward speed from 4.5 up to $5.5 \mathrm{~km} / \mathrm{h}$, energy requirements will increase from 13 to 15 , from 17 to 19 and from 19.5 to $25 \mathrm{~kW}$-h/fed under the same previous conditions. The decrease in energy requirements by increasing forward speed up to $4.5 \mathrm{~km} / \mathrm{h}$ is attributed to the increase in field capacity, while the increase in energy requirements by increasing 


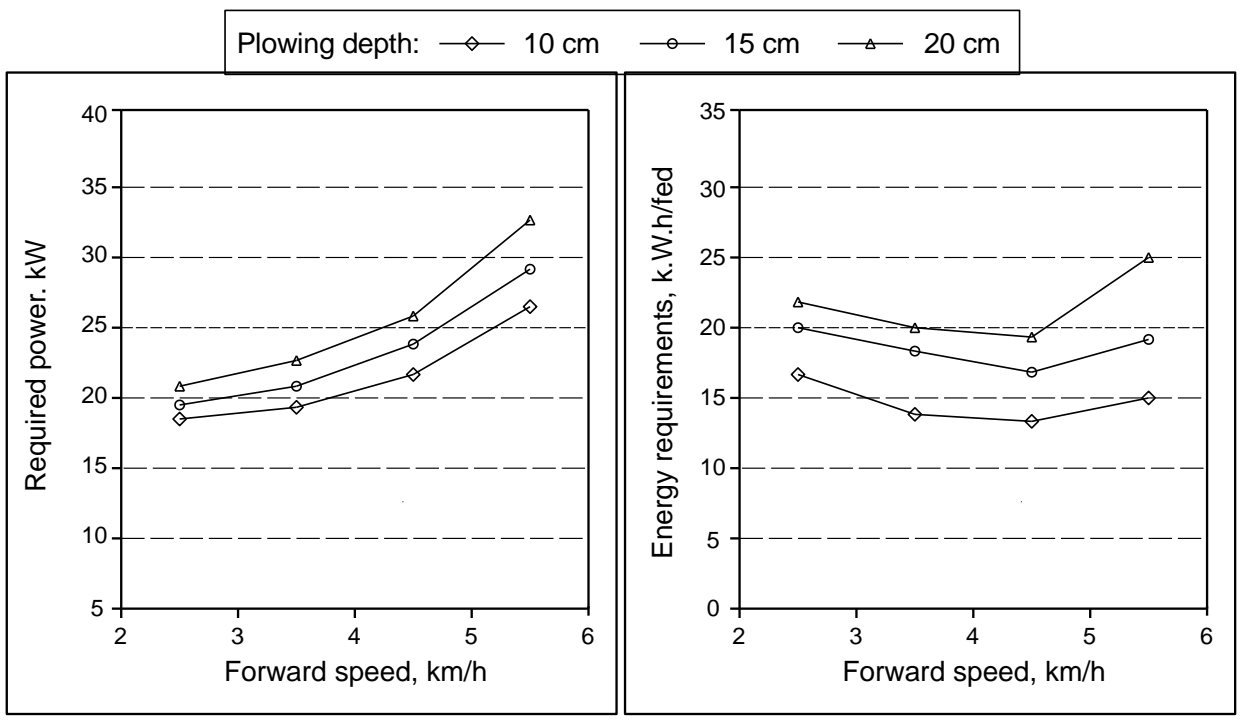

Fig. (8): Effect of machine forward speed on required power and energy requirements under different plowing depths.

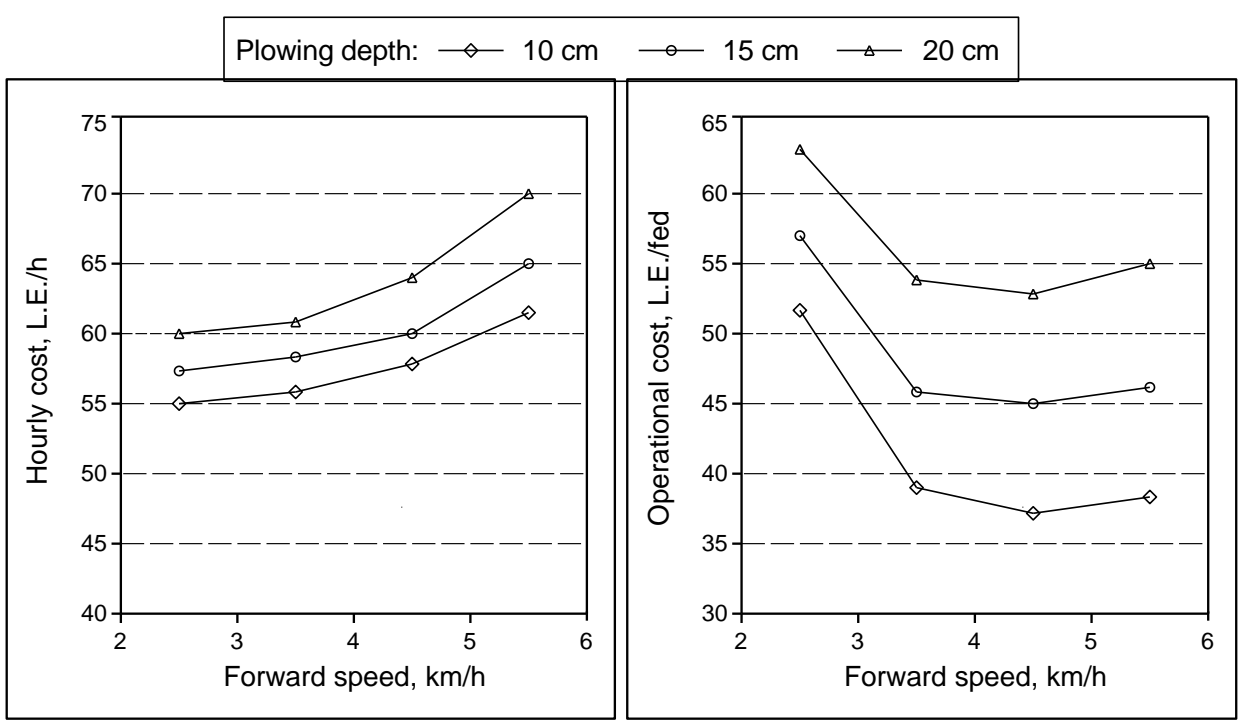

Fig. (9): Effect of machine forward speed on hourly cost and operational cost under different plowing depths. 
forward speed from 4.5 up to $5.5 \mathrm{~km} / \mathrm{h}$ is due to that the rate of increase in power is more than the rate of increase in field capacity.

\section{Effect of some operating parameters on operational cost}

From the economical point of view, results show that the hourly cost increased as the forward speed increased, while the vice versa was noticed with the operational cost which decreased in the speed range from 2.5 up to $4.5 \mathrm{~km} / \mathrm{h}$, while any further increase in speed more than 4.5 up to $5.5 \mathrm{~km} / \mathrm{h}$ operational cost will increase Results in Fig.(9) show that increasing forward speed from 2.5 to $5.5 \mathrm{~km} / \mathrm{h}$, increased hourly cost from 55 to 62 , from 57 to 65 and from 60 to 70 L.E./h, at plowing depths of 10,15 and $20 \mathrm{~cm}$ respectively. Referring to the operational cost, results also show that increasing forward speed from 2.5 to $4.5 \mathrm{~km} / \mathrm{h}$ decreased operational cost from 52 to 37 , from 57 to 45 and from 63 to 53 L.E. /h. Any further increase in speed from 4.5 up to $5.5 \mathrm{~km} / \mathrm{h}$, operational cost will increase from 37 to 38 , from 45 to 46 and from 53 to 55 L.E. /h.

The decrease in operational cost by increasing forward speed is attributed to the increase of machine field capacity, while the increase in operational cost by increasing forward speed from 4.5 up to $5.5 \mathrm{~km} / \mathrm{h}$ is due to that the rate of increase in hourly cost is more than the rate of increase in field capacity.

The obtained data also show that increasing plowing depth increased both hourly and operational costs. Increasing plowing depth from $10 \mathrm{~cm}$ to $20 \mathrm{~cm}$ increased the hourly cost from 56 to $61 \mathrm{~L} . \mathrm{E} . / \mathrm{h}$, also increased operational cost from 39 to 54 L.E./fed at a forward speed of $3.5 \mathrm{~km} / \mathrm{h}$. This increase in both hourly and operational costs by increasing plowing depth is attributed to the increase in soil resistance resulting in high fuel consumption and low field capacity under high depths.

\section{Comparison between the manufactured combination machine and the traditional method}

The above mentioned results show that the combination machines are 
beneficial to the farmer in that the components can be used separately if required, that they reduce the number of machine passes, consequently reduce the danger of soil compaction and that they also reduce labor hours, energy and costs.

Comparing the manufactured combination machine with the traditional method, results show that, the total energy requirements using the manufactured combination machine was less than with the use of the traditional method. The energy values were 19.5 and $53.5 \mathrm{~kW}-\mathrm{h} / \mathrm{fed}$ using the manufactured combination machine and the traditional method respectively. Also the total operational cost using the manufactured combination machine was less than with the use of the traditional method. The operational cost values were 53 and 134 L.E./fed using the manufactured combination machine and the traditional method respectively. The main reason for the energy and cost reduction under the use of the manufactured combination machine is attributed to the fact that the manufactured machine was operated as a multi-purposes machine for seed bed preparation, water harvesting and planting in one pass.

\section{CONCLUSIONS}

The experimental results reveal that energy requirements as well as criterion costs were minimum while crop yield and water use efficiency were maximum under the following conditions:

- The use of the manufactured combination machine instead of using the traditional method to reduce the number of machine passes, consequently reduce the danger of soil compaction.

- Operate the manufactured machine at a forward speed of between 3.5 to $4.5 \mathrm{~km} / \mathrm{h}$.

- Operate the developed machine at a plowing depth of between 10 to $15 \mathrm{~cm}$. 


\section{REFERENCES}

Awady, M. N. (1978). Tractor and farm machinery . Txt bk., Col. Ag., Ain Shams U.: 146-167.

Black, C.A; D.D. Evan; J.L. White; L.E. Ensimenger and L.E. Clark (1965). Methods of soil analysis. Publisher Wisconsin, USA.

Cuenca, R.H. (1989). Irrigation system - An Engineering Approach. Prentic - Hall, Inc., Englewood cliffs, NJ. 552pp.

FAO (1993). Field measurements of soil erosion and runoff. Soils Bull. No (68). Rome, Italy.

Hackwell, S.G., Rochester, E.W., Yoo, K.H., Burt, E.C. \& Monroe, G.E. (1991). Impact of reservoir tillage on water intake and soil erosion. Transactions of the American Society of Agricultural Engineers, 34, 436-442.

Hansen, H, and W. Trimmer (1997). Irrigation Runoff Control Strategies. Oregon State University Extension Service Publication. PNW 287.

Hunt, D. (1983). Farm power and machinery management. 8th Ed. Iowa state Univ., Press Ames, Iows, USA: 364-368.

Patrick, C., C. Kechavarzi, I. T. James , M. O'Dogherty \& R. J. Godwin (2007). Developing reservoir tillage technology for semiarid environments. British Society of Soil Science, Soil Use and Management, 23, 185-191.

Rochester, E.W., Hill, D.T. \& Yoo, K.H. (1994). Impact of reservoir tillage on run-off quality and quantity. Transactions of the American Society of Agricultural Engineers, 37(4), 1183-1186.

Ventura, E., Norton, L. D., Ward, K, López-Bautista, M., and TapiaNaranjo, A. (2003). A New Reservoir Tillage System for Crop Production in Semiarid Areas. 2003 ASAE Annual Meeting. American Society of Agricultural Engineers. 


\section{الملخص العربيى}

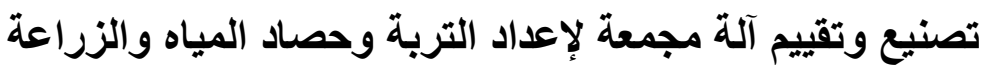

\section{تحت ظروف الزراعات المطرية}

د. محمود مصطفى على على**

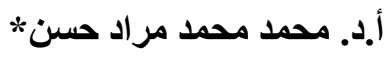

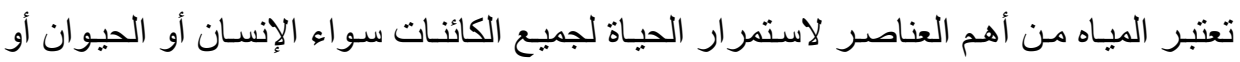

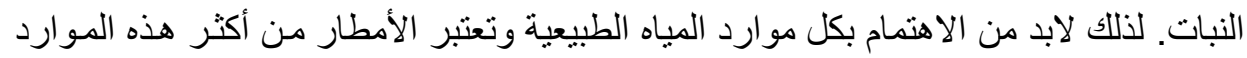

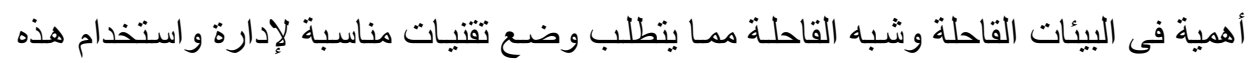
الأمطار وخفض الفاقد منها. ومن الممكن رفع كفاءة استخدام مياه الأمطار عن طريـق استخدام التكنولوجيا الحديثة لحصاد المياه. لذلك كاتت أهداف هذه الاراسة كالآتى:

ـ تطـوير وتصـنيع آلـة مجمعـة لاسـتخدامها فـى إعـداد التربـة وحصساد ميـاه الأمطسار و الزر اعة فى مناطق الزر اعات المطرية.

ـ تحديد قيم عو امل التشغيل المثلى و التى تؤثر على أداء الآلة المصنعة.

- تقييم الآلة المصنعة اقتصاديا مقارنة بالطريقة التقليدية. هذا وتقوم الآلة بعدة عمليات فى مشوار واحد حيث تعمل على: - إجر اء عملية الحرث باستخدام أربع أسلحة على العمق المناسب لإعداد التربـة (وحدة (الحرث)

- إجر اء عملية الزر اعة الآلية بسطارة ذات سبعة سطور (وحدة الزراعة)

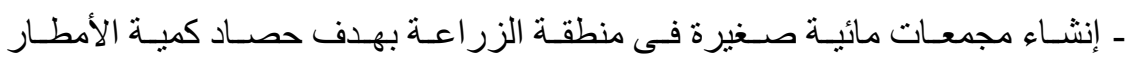
والاحتفاظ بها فى منطقة انتشار الجذور (وحدة حصاد مياه الأمطار).

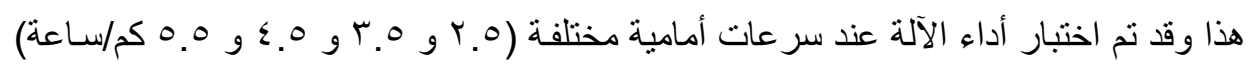

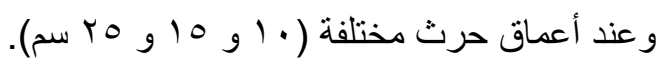
وقد تم تقييم الأداء أخذا فى الاعتبار كل من الكثافـة الظاهريـة ومعدل تسرب الميـاه فى التربـة و معدل الجريان السطحى وكفاءة استخدام المياه و معدل الأداء و الكفاءة الحقلية و القدرة والطاقة وكذلك تكاليف التشغيل.

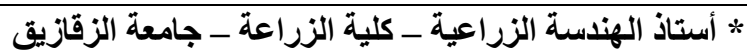

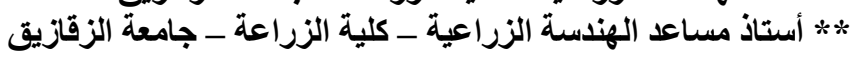




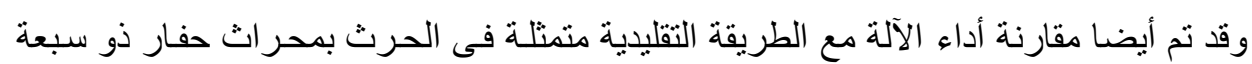

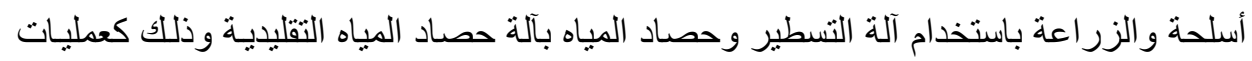
منفصلة.

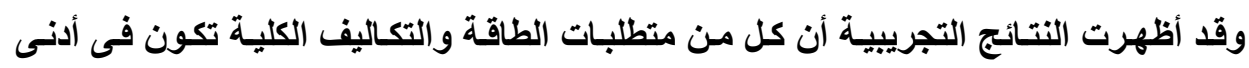

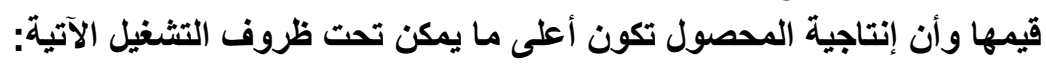

ـ استخدام الآلـة المجمعة فهى عملية إعداد التربـة وحصـاد الميـاه و الزر اعـة بـدلا مـن

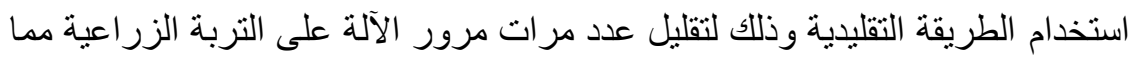
يقلل من خطورة كبس التربة ودرجة احتفاظها بالماء.

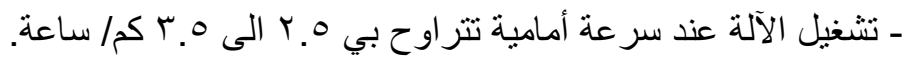
- ضبط عمق الحرث ما بين • ال الى 10 سم. 